Research paper

\title{
Changes in technological properties and microstructure of clayey raw materials from the Corumbataí Formation upon drying: Relevance to dry route tilemaking process
}

\author{
Andrezza de Almeida Azzi ${ }^{\mathrm{a}, *}$, Peter Uhlík ${ }^{\mathrm{b}}$, Marek Osackýb ${ }^{\mathrm{b}}$, Antenor Zanardo ${ }^{\mathrm{c}}$, Helena Palkovád \\ ${ }^{a}$ CAPES Foundation, Ministry of Education of Brazil, 70040020 Brasília, DF, Brazil \\ b Department of Economic Geology, Faculty of Natural Sciences, Comenius University in Bratislava, Mlynská dolina, Ilkovičova 6, 84215 Bratislava, Slovak Republic \\ ${ }^{\mathrm{c}}$ Department of Petrology and Mineralogy, University of São Paulo State - UNESP, 13506900 Rio Claro, SP, Brazil \\ d Institute of Inorganic Chemistry, Slovak Academy of Sciences, Dúbravská cesta 9, 84536 Bratislava, Slovak Republic
}

\section{A R T I C L E I N F O}

\section{Keywords:}

Ceramic tiles

Dehydration of smectite

Forced drying

Raw ceramic materials

Technological characterization

\begin{abstract}
A B S T R A C T
The Ceramic District of Santa Gertrudes (CDSG) is the most important producer of ceramic floor and wall tiles in Brazil. Industries that produce ceramic tiles by dry route process have researched new technologies to dry the Corumbataí Formation (Fm) raw materials. It is due to environmental problem related to the dust emission in the air, produced by beneficiation areas where the raw ceramic materials have been dried. Laboratory experiment and technological test, simulating the current tile production processes in the CDSG, were performed in the present study in order to better understand the role of temperature on clayey rocks from Corumbataí (Fm) and to avoid losses in the current tile production process. Three different illitic raw materials of different degree of weathering and compactness (hard, intermediate and soft) already used to compose the ceramic batch were dried by sunlight and forced drying at $100{ }^{\circ} \mathrm{C}, 200{ }^{\circ} \mathrm{C}$ and $300{ }^{\circ} \mathrm{C}$. Results after forced drying have shown changes at the raw material morphology and size distribution after grinding; also the progressive dehydration of the expandable clay minerals which have caused the plasticity and consistency loss of the raw material and consequently affected the quality of the product. Ceramic bodies presented decreasing linear shrinkage values, loss in their bending strength, and horizontal cracks in some bodies whose raw materials were forced to dry at $200{ }^{\circ} \mathrm{C}$ and $300{ }^{\circ} \mathrm{C}$.
\end{abstract}

\section{Introduction}

The worldwide production of ceramic tiles is rapidly increasing. Globally, the tiles production increased by $>40 \%$ since 2005 until 2014 (ACIMAC/MECS, 2015). This increase is mainly connected with urban population growth (ACIMAC/MECS, 2015). More than $90 \%$ of tiles produced are for sale in nearby markets (ACIMAC/MECS, 2015).

With the tile production of 899 million $\mathrm{m}^{2}$ in 2015 , Brazil is the second largest producer of ceramic products in the world after China (Anfacer, 2016). The Ceramic District of Santa Gertrudes (CDSG), located in the state of São Paulo, is the largest ceramic tiles producer in Brazil (Fig. 1). Nowadays, the CDSG consists of approximately 30 mining sites, 40 beneficiation areas and 35 factories specialized in ceramic manufacturing, consuming annually $>8$ million tons of clay. In the CDSG the clayey raw materials are mainly used for production of ceramic tiles destined to floor and wall indoor applications. Worldwide, ceramic tiles are conventionally manufactured by wet route process, whereas $>70 \%$ of the ceramic tiles in the CDSG are produced by dry route process (Anfacer, 2016).

The growth in tiles production and high demand for clayey raw materials in the past years resulted in a number of studies focused on the characterization of clayey raw materials with potential application in ceramic industry (e.g. Dondi, 1999; Celik, 2010; Galos, 2011; Medhioub et al., 2012; Dondi et al., 2014; Gliozzo et al., 2014; Lahcen et al., 2014; Ouahabi et al., 2014; Oikonomopoulos et al., 2015). Characterization of clayey raw materials (mineralogy, chemistry and surface properties) and investigation of their behavior and changes in technological properties at elevated temperatures are essential to study in order to succeed in the ceramic business (Henry, 1952; Dondi et al., 2014).

In the CDSG, the single raw material, clayey rock from the Corumbataí Formation (Fm), is used for production of ceramic tiles. Clayey raw material is taken from nearby open quarries which decrease production costs (Motta et al., 2004; Cabral Junior et al., 2013). The

\footnotetext{
* Corresponding author at: Av. Nelsia Vannucci 105, ap113 Girassol, 13042104 Campinas, SP, Brazil.

E-mail address: andrezzazzi@gmail.com (A. de Almeida Azzi).
} 


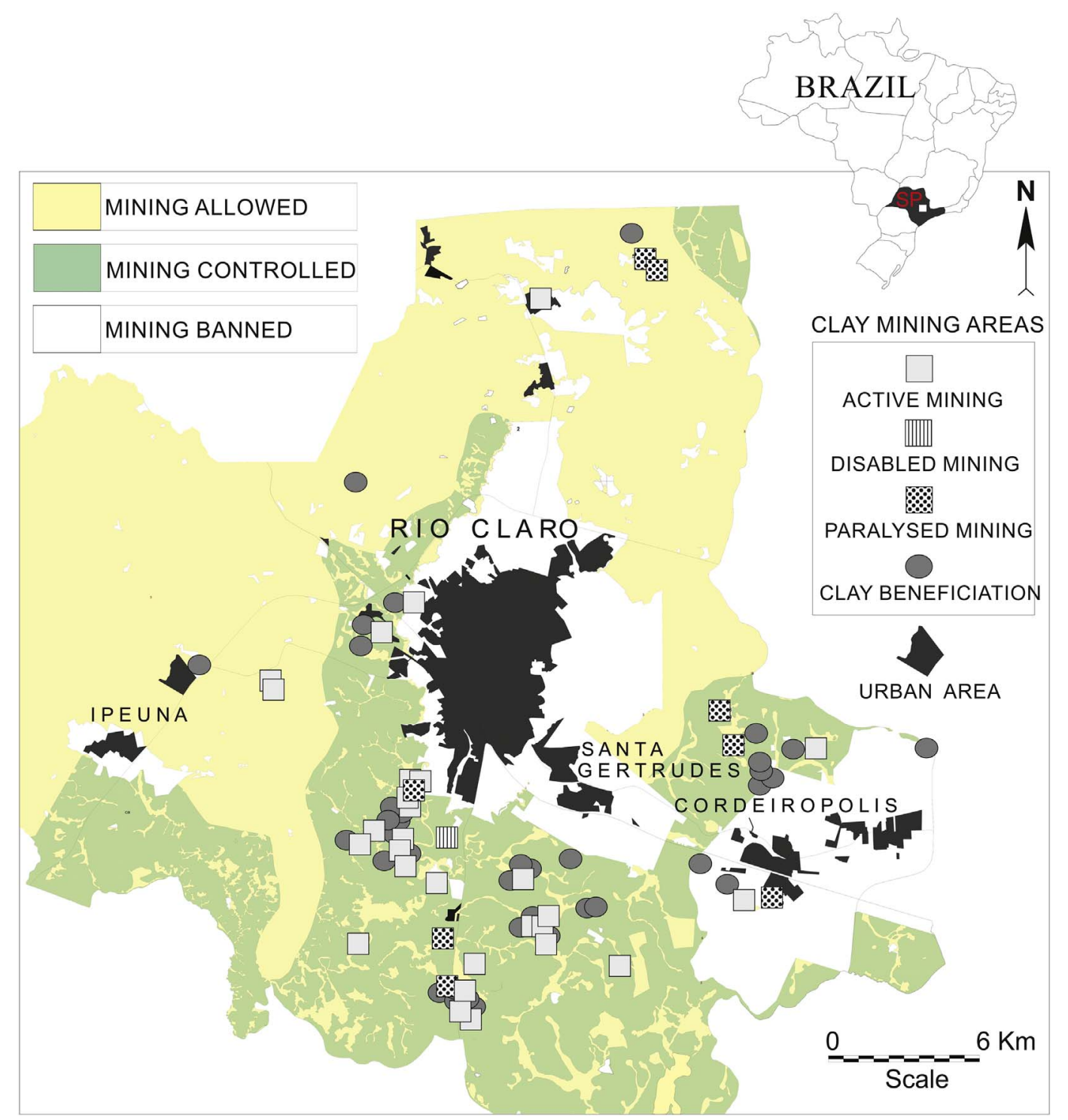

Fig. 1. Schematic figure showing the clay mining locations and clay beneficiation areas in the Ceramic District of Santa Gertrudes - São Paulo State, Brazil (Azzi, 2014).

raw materials have specific characteristics in terms of mineral composition, particle size distribution, low content of organic matter and high fusibility, which impart a unique ceramic performance to these clays (Rocha et al., 2008; Moreno et al., 2012, 2014).

The commercial success of ceramic products is due to a continuous increase of product quality from both technical performance and esthetic viewpoints (Dondi et al., 2014). The quality improvement associated with the innovation of ceramic products and tile making process took place during the last decades in every tilemaking country (Corma, 2008; Nassetti, 1989). However, current boom in the ceramic industry in the CDSG is coupled with some environmental problems. Production of the dust is one of the main problems associated with the dry route tilemaking process used in the CDSG. The dust is produced mainly during sun drying and homogenization of clayey raw materials in beneficiation areas and transportation of the dried clayey raw material to the local ceramic manufactures. At the drying stage, different types of clayey rocks from the Corumbataí (Fm) are mixed together to create a batch of optimal composition. When the rock mixture is homogenized and dried to the moisture content $<5.5 \%$ the raw material proceeds to the next processing step which is dry grinding (Azzi et al., 2015). Emission of fine solid particles into the atmosphere can cause respiratory problems and lowers the quality of water in the rivers. These two negative aspects are emphasized during dry seasons and heavy rainfall events (Christofoletti and Moreno, 2011; Oliveira et al., 2016). In this context, environmental control agencies are pressing to the ceramic manufacturers to replace outdoor drying sites (i.e. beneficiation areas) by indoor forced drying using industrial dryers. However, the batch whose raw materials have been dried using industrial dryers has produced tiles that break and/or crack during the tilemaking process. These negative consequences associated with changing the drying process of raw materials (sunlight drying vs. industrial dryers) may be due to loss of plasticity and consistence of the ceramic bodies which implies insufficient strength to withstand all process along the treadmill transportation until the firing step.

Research focused on new alternatives on how to dry the raw clayey material to match the criteria of ceramic manufacturers is essential for keeping the dry route tilemaking process in the CDSG in commercial operation.

For this purpose, three different types of clayey raw materials from the Corumbataí (Fm) were investigated in the present study. The results of comprehensive characterization of these raw materials are reported in our previous studies (Azzi et al., 2015, 2016). These samples were recognized by the ceramic manufacturers as ones of the worst technological types of raw materials in their category (different degree of 
weathering) used in the CDSG. It is more difficult to dry these raw materials and it takes longer to reach moisture content $<5.5 \mathrm{wt} . \%$. Individually the clayey raw material do not reach the parameters (e.g. linear shrinkage and the bending strength values) required by the international standards. However, the ceramic manufactures use their mutual mixture to improve the batch composition.

The papers evaluating clayey materials for ceramic industry have been focused on the characterization of raw materials (e.g. Gliozzo et al., 2014; Azzi et al., 2016), material after firing (e.g. Njoya et al., 2012; Oikonomopoulos et al., 2015), but predominantly on studies of both states, initial, raw materials together with fired clays (e.g. Sousa and Holanda, 2005; Ferrari and Gualtieri, 2006; Vieira et al., 2008; Celik, 2010; Galos, 2011; Medhioub et al., 2012; Lahcen et al., 2014). In contrast to the previous studies, in our present paper we investigate ceramic properties in a wider range of lower temperatures (up to $\left.300^{\circ} \mathrm{C}\right)$.

Laboratory experiments and technological tests were performed in the present study in order to better understand the implications of different temperatures (up to $300{ }^{\circ} \mathrm{C}$ ) on technological behavior of clayey raw materials from the Corumbataí $(\mathrm{Fm})$ in the current tile making process. Ceramic properties for the clayey raw materials dried by sunlight (the standard) were compared with the raw materials after drying at different temperatures $\left(100,200\right.$ and $\left.300{ }^{\circ} \mathrm{C}\right)$. Overall, the expectation was to judge if the clayey raw materials dried at $100-300{ }^{\circ} \mathrm{C}$ could achieve similar or higher ceramic performance than clayey raw materials dried by sunlight.

\section{Starting materials and methods}

\subsection{Starting materials}

Three clayey raw materials collected from the Corumbataí (Fm) were used in the present study. Samples designated as D (hard), I (intermediate) and $M$ (soft) represent the rocks which underwent a different degree of weathering. These types of clayey materials are used as raw materials for production of ceramic tiles in the CDSG. Samples D and I come from Alfagres mine, containing rocks from the bottom of the Corumbataí (Fm). Sample M is from Pieroni mine, stratigraphically located in the middle part of the Corumbataí (Fm). Characterization (mineral and chemical composition) of the $\mathrm{D}$, I and $\mathrm{M}$ samples and their stratigraphic position within the Corumbataí (Fm) were reported by Azzi et al. (2015, 2016).

The bulk clayey rocks from the Corumbataí (Fm) are dominated by clay minerals associated with quartz, feldspars and minor amount of hematite (Azzi et al., 2016). These rocks are mixtures where different types of clay minerals such as illite, smectite and interstratified illitesmectite coexist in variable amount (Zanardo et al., 2011; Azzi et al., 2016). Sometimes chlorite, interstratified kaolinite-smectite and kaolinite are also present. The clayey rocks from the Corumbataí (Fm) can be classified as silty clays and/or clayey silts (Azzi et al., 2016). Bulk and clay $(<2 \mu \mathrm{m})$ fraction of samples D, I and M were used in this study. For the clay fraction, bulk samples were dried at room temperature overnight and crushed to pass through a $160 \mu \mathrm{m}$ sieve. The clay fraction $(<2 \mu \mathrm{m})$ was separated from the bulk samples by sedimentation in distilled water.

\subsection{Methods}

\subsubsection{Ceramic tiles: technological test}

For technological tests bulk samples D, I and M (30 kg each), having a natural moisture content of 8,18 and $19 \mathrm{wt} . \%$, respectively, were manually homogenized and reduced to a pebble size. After that, part of the samples was dried by sunlight and the other part was dried in the MAITEC oven at different temperatures $\left(100,200\right.$ and $\left.300^{\circ} \mathrm{C}\right)$ for $24 \mathrm{~h}$. Drying of the samples reduced the moisture content to $<5.5 \mathrm{wt} . \%$. After drying, the samples were ground using hammer mill CT-058
SERVITECH, and fractions $<355 \mu \mathrm{m}$ were obtained by sieving. Powder agglomeration was prepared by granulation, adding deionized water until the batch achieves $9.5 \mathrm{wt} . \%$ of moisture. Then, it was homogenized for $24 \mathrm{~h}$ in closed plastic bags. The batch from D, I and $\mathrm{M}$ raw materials dried by sunlight and after drying at 100,200 and $300{ }^{\circ} \mathrm{C}$ were shaped using hydraulic press SERVITECH CT320. Ceramic bodies were prepared using $50 \mathrm{~g}$ of the batch, $10 \times 3.5 \mathrm{~cm}$ mold and different pressing values (between 10 and 16 tons), in order to achieve tiles with density of $2 \mathrm{~g} / \mathrm{cm}^{3}$. Subsequently, the green tiles bending strength were measured using a CC 96-2006 Nannetti Fleximeter. Part of the tiles was put into a hothouse for $24 \mathrm{~h}$ at $105^{\circ} \mathrm{C}$. After that, the tiles were dried and cooled in desiccators with silica gel for $5 \mathrm{~h}$. Bending strength was also measured for the dried tiles according to the ABNT-NBR 13818/ 1997 (ABNT, 1997). However, the distance between the cylindrical supports was set to $60 \mathrm{~mm}$, as in $80 \mathrm{~mm}$ these materials by themselves do not reach the minimal strength to be measured. Linear drying shrinkage was calculated from dimensional changes of the ceramic bodies before (green tiles) and after drying (dried tiles).

The particle size distribution was carried out by laser diffraction technique using the Malvern MSS Mastersizer 2000. An aliquot of the sample was placed in $800 \mathrm{ml}$ of distilled water and dispersed with 3 drops of $10 \%$ solution of sodium hexametaphosphate. Measurement was performed according to the following parameters: Pump speed 2400 RPM, Ultrasonic displacement 12:50 and Ultrasonic timer 00:30.

Liquid limit (LL) determination was carried out with a Casagrande apparatus and the fall cone penetrometer (Christaras, 1991) while the plastic limit (PL) was determined using the $3 \mathrm{~mm}$ thread method. In addition, the plasticity index (Ip) was calculated based on the arithmetic difference of the LL and PL. Tests were performed in duplicates at a room temperature of $25{ }^{\circ} \mathrm{C}$. To measure the workability of the batch, consistency analysis was performed using a fall cone penetrometer ( $30^{\circ}$ cone and $80 \mathrm{~g}$ of samples). Different amount of deionized water was used for each sample. For samples D, I and M 27, 32.7 and $35.4 \mathrm{wt} . \%$ of moisture were used, respectively, resulting in the $17 \mathrm{~mm}$ of cone penetration (for samples dried by sun). The same initial value of cone penetration was used for comparing samples D, I and M properties. Results were obtained by the arithmetic average of four measurements for each step. The main principle behind this method is that with decreasing of cone penetration the consistency of analysed samples increases (Campos et al., 1999; Moreno et al., 2016).

A magnifying glass was used to study the grain morphology after grinding (before pressing the ceramic bodies), and the surface of the ceramic bodies, to identify tiny cracks. Small pieces of ceramic bodies were coated with carbon and investigated by scanning electron microscope (SEM) JEOL JXA-840A in a mode of secondary electrons (SE) at accelerating voltage $15 \mathrm{kV}$, beam current $30 \mathrm{nA}$ and working distance $8 \mathrm{~mm}$.

\subsubsection{Ceramic clays: laboratory experiment and characterization}

The rehydration test was performed using $1.2 \mathrm{~g}$ of samples of $<2 \mu \mathrm{m}$ fraction. Prior to the test, all samples were pre-treated by drying at $105^{\circ} \mathrm{C}$ for $24 \mathrm{~h}$. To prevent rehydration of dried samples, they were cooled in desiccators with dehydrated $\mathrm{CaCl}_{2}$, as sorbent, for $4 \mathrm{~h}$. The $\mathrm{CaCl}_{2}$ in desiccators was activated by heating at $240{ }^{\circ} \mathrm{C}$ for $2 \mathrm{~h}$. The pre-treatment ensured the same starting conditions for samples $\mathrm{D}$, I and $\mathrm{M}$. Then, $1 \mathrm{~g}$ of pre-treated samples was put in oven at $100{ }^{\circ} \mathrm{C}$ for $24 \mathrm{~h}$ and subsequently cooled in desiccator for $5 \mathrm{~h}$. After that, the samples weights were determined using a Sartorius BP $210 \mathrm{~S}$ balance to calculate the weight losses after drying. The same procedure was repeated for samples dried at temperatures of $200^{\circ} \mathrm{C}$ and $300{ }^{\circ} \mathrm{C}$. After the weight measurements, samples were kept outside the desiccators, in the laboratory conditions $\left(20^{\circ} \mathrm{C}\right.$ and $\left.30 \% \mathrm{RH}\right)$ for $24 \mathrm{~h}$ and their moisture absorption was monitored after 1,14 and $24 \mathrm{~h}$.

Thermal analysis of the samples $(<2 \mu \mathrm{m}) \mathrm{D}$, I and M was performed using a TA Instruments - 2690 TG/DTA/DSC simultaneous analyzer STA 449 F1 Jupiter (NetzschGeratebau GmbH). All measurements were 
performed in the temperature range of $30-1000{ }^{\circ} \mathrm{C}$ using $30 \mathrm{mg}$ of the sample held in a Pt-Ir crucible. Heating rate of $10^{\circ} \mathrm{C} / \mathrm{min}$ and an air flow rate $50 \mathrm{~cm}^{3} / \mathrm{min}$ were maintained. Manipulations with collected data were performed using NETZSCH Proteus software.

The XRD analysis of clay fraction after drying test was performed. The oriented preparations (air dried and ethylene glycol vapours saturated) was carried out using a Philips 1075 diffractometer with $\mathrm{Cu} \mathrm{K \alpha}$ radiation and a graphite monochromator, operating at $20 \mathrm{~mA}$ and $35 \mathrm{kV}$. The step size was $0.02^{\circ} 2 \theta$ and the counting time $0.8 \mathrm{~s}$ per step. Oriented preparations were prepared by the Millipore filter transfer method (Moore and Reynolds Jr., 1997). The ethylene glycol solvation was performed at $60^{\circ} \mathrm{C}$ for $12 \mathrm{~h}$. The X'Pert HighScore Plus software with the Inorganic Crystal Structure Database (ICDS) was used to evaluate the XRD patterns. The reference intensity ratio (RIR) method was used for quantifying the clay minerals in the samples dried by sunlight (Moore and Reynolds Jr., 1997).

Infrared spectra of samples after drying test were obtained using a Nicolet Magna 750 Fourier transform infrared spectrometer. The $\mathrm{KBr}$ pressed disc technique ( $1 \mathrm{mg}$ of sample and $200 \mathrm{mg}$ of $\mathrm{KBr}$ ) was used to measure spectra in the middle infrared region (MIR, $4000-400 \mathrm{~cm}^{-1}$ ). For each sample 128 scans with a resolution of $4 \mathrm{~cm}^{-1}$ was recorded. Spectral manipulations were performed using the OMNIC software package (Nicolet Instruments Corp.).

\section{Results}

\subsection{Particle size distribution}

Particle size distributions for raw materials dried by sunlight and forced to dry at $100{ }^{\circ} \mathrm{C}, 200{ }^{\circ} \mathrm{C}$ and $300^{\circ} \mathrm{C}$ have shown differences between sample D (bimodal distribution, Fig. 2) and samples $\mathrm{M}$ and I (unimodal distribution, Fig. 2). The technological test, primarily, has revealed important changes during the ceramic body preparation. Particle size analysis for the raw materials after grinding (Fig. 2) shows that sun-dried samples D, I and M have the largest amount of the 8-62 $\mu \mathrm{m}$ size fraction. The second most abundant particle size fraction, between 1 and $8 \mu \mathrm{m}$, accounts for about $30 \%$ of all particles. Sample D has the largest amount of coarse fraction $(>125 \mu \mathrm{m})$ which account for $13 \%$, while sample I and $\mathrm{M}$ contain 3 and $0 \%$ of coarse fraction, respectively. After forced drying, all samples showed an increase in the coarse fraction correlated to the increase of the drying temperature (Fig. 3). The shape of the curves did not change, keeping the bimodal particle size distribution for sample D and unimodal particle size distribution for samples I and M. Curves with bimodal shape of particle size distribution are characteristic of hard materials. Low resistance to grinding produce unimodal shape and higher amount of fine grains as verified to sample I and M. Since, particle shapes were studied by the magnifying glass; grains with needle shape were recognized, especially in the coarse fraction. Hence, particle size distribution showed a few percentages of particle size over the cutting sieve $(355 \mu \mathrm{m})$, that is explained by the needle shape of grains as mentioned before. Such phenomenon increased when samples were dried at higher temperatures and confirmed that raw materials started to be hardened and consolidated.

\subsection{Plasticity analyses}

According to Ryley and Sherwood (1970) the fall cone penetrometer yields liquid limit results comparable with those obtained by the Casagrande method and also offering the advantage of less variability due to operator technique. Besides, the Casagrande liquid limit may be correlated to the correct fall cone penetration depth, samples with different particle size cause a variation between the two methods (Christaras, 1991). Liquid limit, plasticity index and consistency analyses were carried out for samples D, I and M after grinding and sieving $(<355 \mu \mathrm{m})$. Figs. 4 and 5 show the plasticity chart and the consistency
Volume

$(\%)$
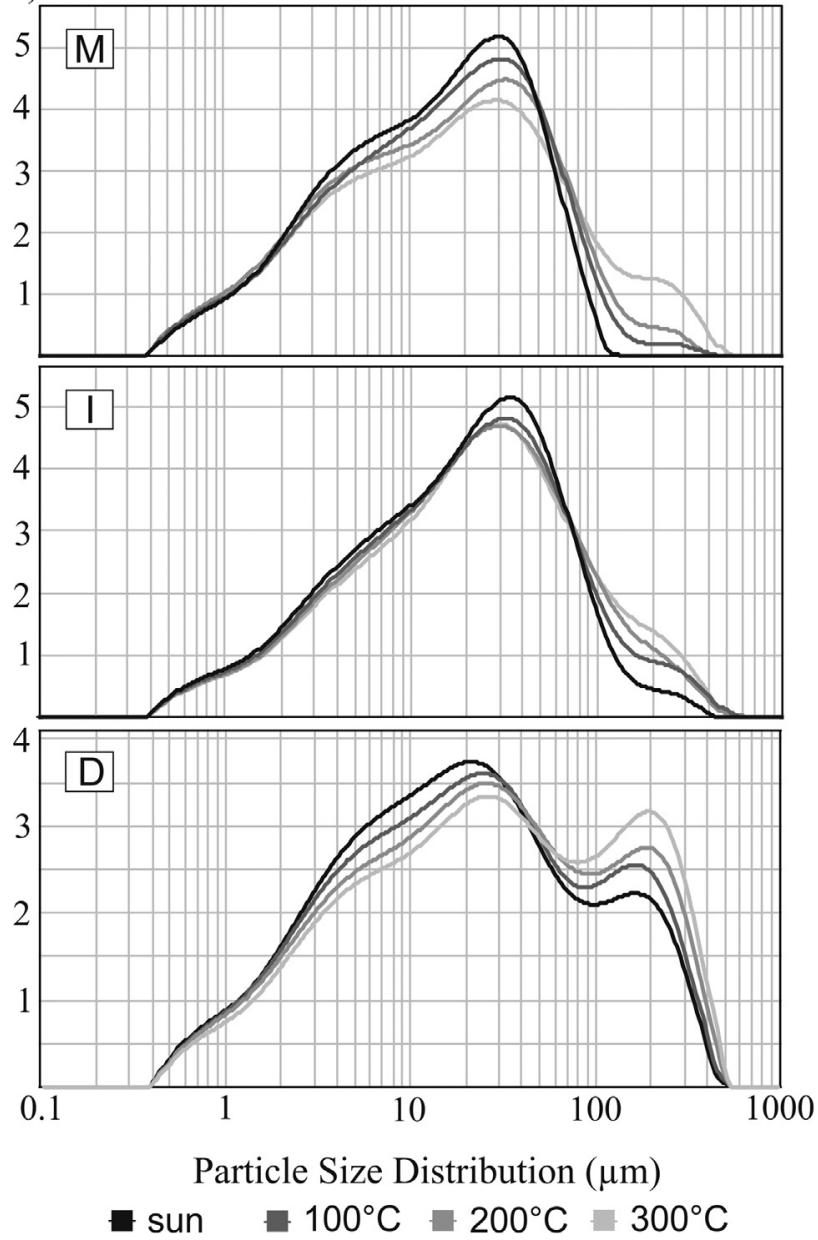

Fig. 2. Particle size distribution curves of samples D, I and $M$ dried by sunlight (sun), forced dried at $100{ }^{\circ} \mathrm{C}, 200^{\circ} \mathrm{C}$ and $300{ }^{\circ} \mathrm{C}$, dry grinded in hammer mill and sieved at $355 \mu \mathrm{m}$.

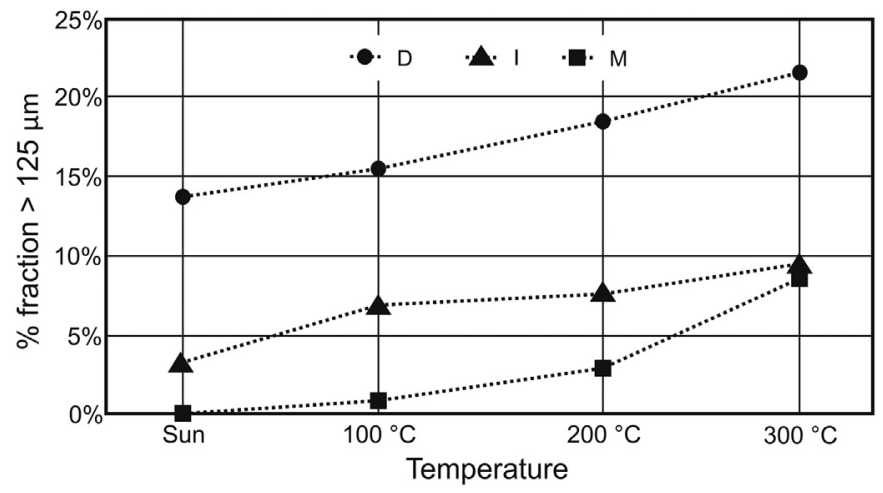

Fig. 3. The increase of fraction $>125 \mu \mathrm{m}$ after various drying conditions. Dotted line is provided to guide the eye only.

results, respectively, for the tested samples. Due to higher phyllosilicates content and finer particles after grinding, sample $\mathrm{M}$ dried showed a superior liquid limit $(\mathrm{LL}=37.7 \%)$ and plasticity index (PL $=9.9 \%)$. After forced drying at $100{ }^{\circ} \mathrm{C}$, the same sample showed similar values $(\mathrm{LL}=37.9 \%$, PI $=9.8 \%)$ while the liquid limit and plasticity index values were lower at $200{ }^{\circ} \mathrm{C}(\mathrm{LL}=35.6 \%, \mathrm{PI}=7.4 \%)$ and $300{ }^{\circ} \mathrm{C}$ $(\mathrm{LL}=35.6 \%, \mathrm{PI}=7.4 \%$ and $\mathrm{LL}=33.4 \%, \mathrm{PI}=4.7 \%)$. The similar behavior was observed for samples I and D (Fig. 4). Sample I dried by 


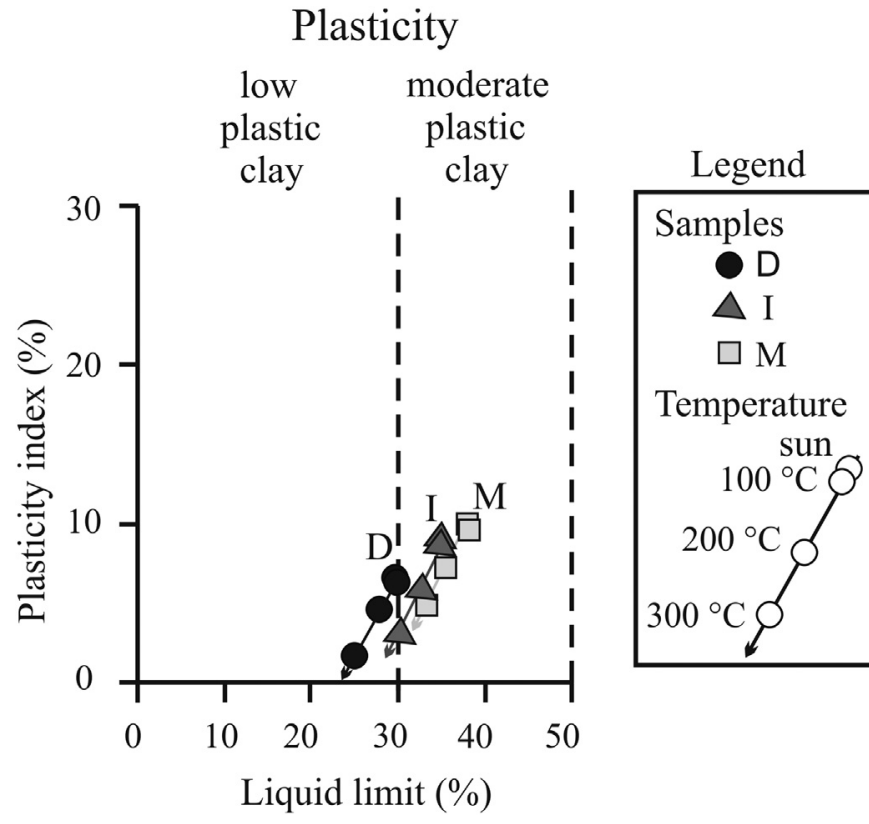

Fig. 4. Plasticity chart, after Holtz and Kovacs (1981) for samples D, I and M dried by sunlight, and forced dried at $100{ }^{\circ} \mathrm{C}, 200^{\circ} \mathrm{C}$ and $300{ }^{\circ} \mathrm{C}$. Schematic figure on the right side indicates the temperature sequence of samples plotted on the chart.

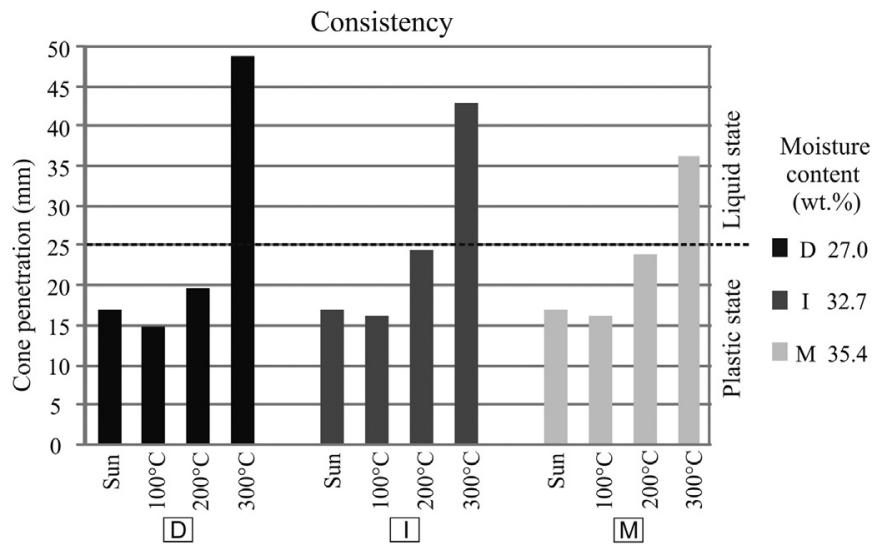

Fig. 5. Consistency chart showing cone penetration analyses of samples D, I and M dried by sunlight and forced dried at $100{ }^{\circ} \mathrm{C}, 200^{\circ} \mathrm{C}$ and $300^{\circ} \mathrm{C}$.

sunlight showed an intermediate liquid limit (34.4\%) and plasticity index (9\%). After forced drying at $100{ }^{\circ} \mathrm{C}, 200{ }^{\circ} \mathrm{C}$ and $300{ }^{\circ} \mathrm{C}$ sample I values have changed to ( $\mathrm{LL}=34.8 \%, \quad \mathrm{PI}=8.8 \%$ ), $(\mathrm{LL}=32.8 \%$, $\mathrm{PI}=6 \%)$ and $(\mathrm{LL}=30.1 \%, \mathrm{PI}=3 \%)$, respectively. Samples D dried by sunlight showed lower liquid limit (29.1\%) and plasticity index (6.5\%). Lower values for sample D compared to the samples I and $\mathrm{M}$ are related to the lower phyllosilicates content. After forced drying at $100{ }^{\circ} \mathrm{C}$, $200{ }^{\circ} \mathrm{C}$, and $300{ }^{\circ} \mathrm{C}$, LL and PI values for samples D gradually decreased from $29.4 \%$ to $25.6 \%$ and from $6.4 \%$ to $1.6 \%$, respectively.

\subsection{Consistency analyses}

Samples D, I and M forced to dry at different temperatures, presented different consistency. In order to establish a comparison among the samples, deionized water was added to samples $\mathrm{D}$, I and $\mathrm{M}$ to get 27.0, 32.7 and $35.4 \mathrm{wt} \%$ moisture content, respectively, and result relate to the same cone penetration value, in this case $17 \mathrm{~mm}$. The same moisture content was kept also for samples that were forced to dry at $100{ }^{\circ} \mathrm{C}, 200^{\circ} \mathrm{C}$ and $300^{\circ} \mathrm{C}$ (Fig. 5). Comparison of forced dried samples with those dried by sunlight indicates that for $100^{\circ} \mathrm{C}$ forced dried
Table 1

Technological properties of the ceramic bodies.

\begin{tabular}{|c|c|c|c|}
\hline Sample & $\begin{array}{l}\text { Linear drying } \\
\text { shrinkage }\end{array}$ & $\begin{array}{l}\text { Bending strength } \\
\text { green tiles }\end{array}$ & $\begin{array}{l}\text { Bending strength } \\
\text { dried tiles }\end{array}$ \\
\hline & $(\%)$ & (MPa) & (MPa) \\
\hline D sun & $0.471 \pm 0.01$ & $1.220 \pm 0.12$ & $4.751 \pm 0.22$ \\
\hline D $100^{\circ} \mathrm{C}$ & $0.368 \pm 0.01$ & $1.075 \pm 0.05$ & $2.896 \pm 0.19$ \\
\hline D $200{ }^{\circ} \mathrm{C}$ & $0.329 \pm 0.01$ & $1.187 \pm 0.06$ & $3.677 \pm 0.28$ \\
\hline D $300^{\circ} \mathrm{C}$ & $0.290 \pm 0.01$ & $1.098 \pm 0.09$ & $3.247 \pm 0.16$ \\
\hline I sun & $0.590 \pm 0.01$ & $1.767 \pm 0.18$ & $6.224 \pm 0.62$ \\
\hline I $100^{\circ} \mathrm{C}$ & $0.552 \pm 0.01$ & $1.157 \pm 0.05$ & $5.551 \pm 0.17$ \\
\hline I $200^{\circ} \mathrm{C}$ & $0.511 \pm 0.01$ & $2.049 \pm 0.02$ & $5.786 \pm 0.42$ \\
\hline I $300{ }^{\circ} \mathrm{C}$ & $0.410 \pm 0.01$ & $1.742 \pm 0.10$ & $5.424 \pm 0.08$ \\
\hline M sun & $0.379 \pm 0.01$ & $1.605 \pm 0.17$ & $5.723 \pm 0.27$ \\
\hline $\mathrm{M} 100^{\circ} \mathrm{C}$ & $0.312 \pm 0.01$ & $2.010 \pm 0.24$ & $5.139 \pm 0.21$ \\
\hline M $200{ }^{\circ} \mathrm{C}$ & $0.240 \pm 0.01$ & $2.073 \pm 0.11$ & $4.963 \pm 0.14$ \\
\hline M $300^{\circ} \mathrm{C}$ & $0.191 \pm 0.01$ & $2.015 \pm 0.16$ & $5.341 \pm 0.36$ \\
\hline
\end{tabular}

samples consistency was slightly higher; D (14.9 mm), I (16 mm) and M $(16.2 \mathrm{~mm})$. The opposite behavior was observed for samples forced dried at $200{ }^{\circ} \mathrm{C}$ and $300{ }^{\circ} \mathrm{C}$. For samples I and $\mathrm{M}$ forced dried at $200{ }^{\circ} \mathrm{C}$, the loss of consistency almost reached the liquid state. For samples D, I and $\mathrm{M}$ forced dried at $300{ }^{\circ} \mathrm{C}$, the loss of consistency was higher than the cone penetration measurement capacity (graduation of $31 \mathrm{~mm}$ ). Those values for samples dried at $300{ }^{\circ} \mathrm{C}$ were calculated by straight line equation. The loss of consistency is related to increasing of coarser fraction after forced drying (Figs. 2 and 3 ) and to the loss of absorption ability (see later).

\subsection{Technological parameters}

In order to verify the changes on the ceramic bodies as consequence of raw materials forced drying, ceramic bodies were prepared for samples $\mathrm{D}$, I and $\mathrm{M}$ that were previously dried by sunlight (as reference), and forced dried at $100{ }^{\circ} \mathrm{C}, 200{ }^{\circ} \mathrm{C}$ and $300{ }^{\circ} \mathrm{C}$. Their technological parameters were tested and results are shown in Table 1. Densities of around $2.0 \mathrm{~g} / \mathrm{cm}^{3}$ were calculated to prepare the green tiles (name referred to the ceramic bodies just after shaped) for all samples. However, to achieve the same density, with the same amount of powder was necessary to use different pressure for pressing. Sample D and I demonstrated quite the same behavior. Samples that were forced to dry needed a bit more pressure for pressing (10 tons for sun dried samples and 11 tons for forced dried samples) in order to keep the same density. Sample M needed more pressure (15 and 16 tons) to produce ceramic bodies with the same density like samples D and I. This could be explained by different particle size distributions among the samples (Fig. 2). Sample $M$ is finer, compared to D and I. M, is practically without coarser fraction $>125 \mu \mathrm{m}$ (Fig. 3) and has slightly larger amount of finer particles $<10 \mu \mathrm{m}$ ( $42 \%$ for $\mathrm{M}$ vs. $38 \%$ for D and $35 \%$ for I). Similar behavior was reported for bentonites compaction; higher pressures were needed for the finer fractions than for the coarser fractions (Adamcová et al., 2009).

Sample $\mathrm{M}$ has the lowest linear shrinkage from all three studied samples. Sample M forced dried at $200{ }^{\circ} \mathrm{C}$ and $300{ }^{\circ} \mathrm{C}$ had produced tiles that showed fragile edges and horizontal cracks (Fig. 6). Moreover, tiles from sample $\mathrm{M}$ have changed the color from light purple (sunlight dried material) to light red (material after forced drying at $300^{\circ} \mathrm{C}$ ). This may be due to iron oxidation, despite the non-expressiveness of such reaction in the thermal analyses curves (Fig. 7).

\subsection{Scanning electron microscopy}

SEM images for D, I and M green tiles dried by sunlight (Fig. 8) showed higher amount of larger particles for sample D and higher amount of finer particles for I and M (Fig. 2). Such observation was in 

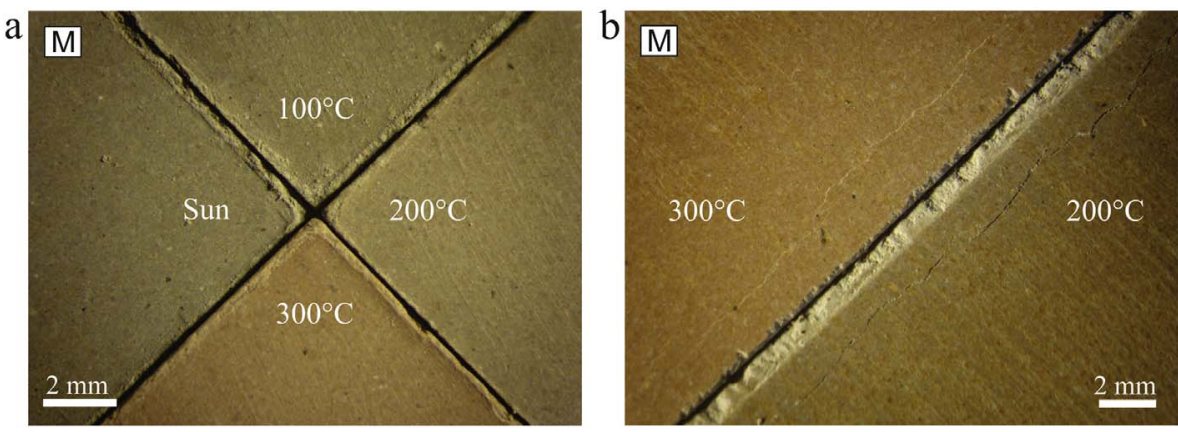

Fig. 6. Tiles from sample M showing the changes of color from different drying temperatures (sunlight, $100{ }^{\circ} \mathrm{C}, 200{ }^{\circ} \mathrm{C}$ and $300{ }^{\circ} \mathrm{C}$ ) and the cracks produced at $200{ }^{\circ} \mathrm{C}$ and $300^{\circ} \mathrm{C}$.
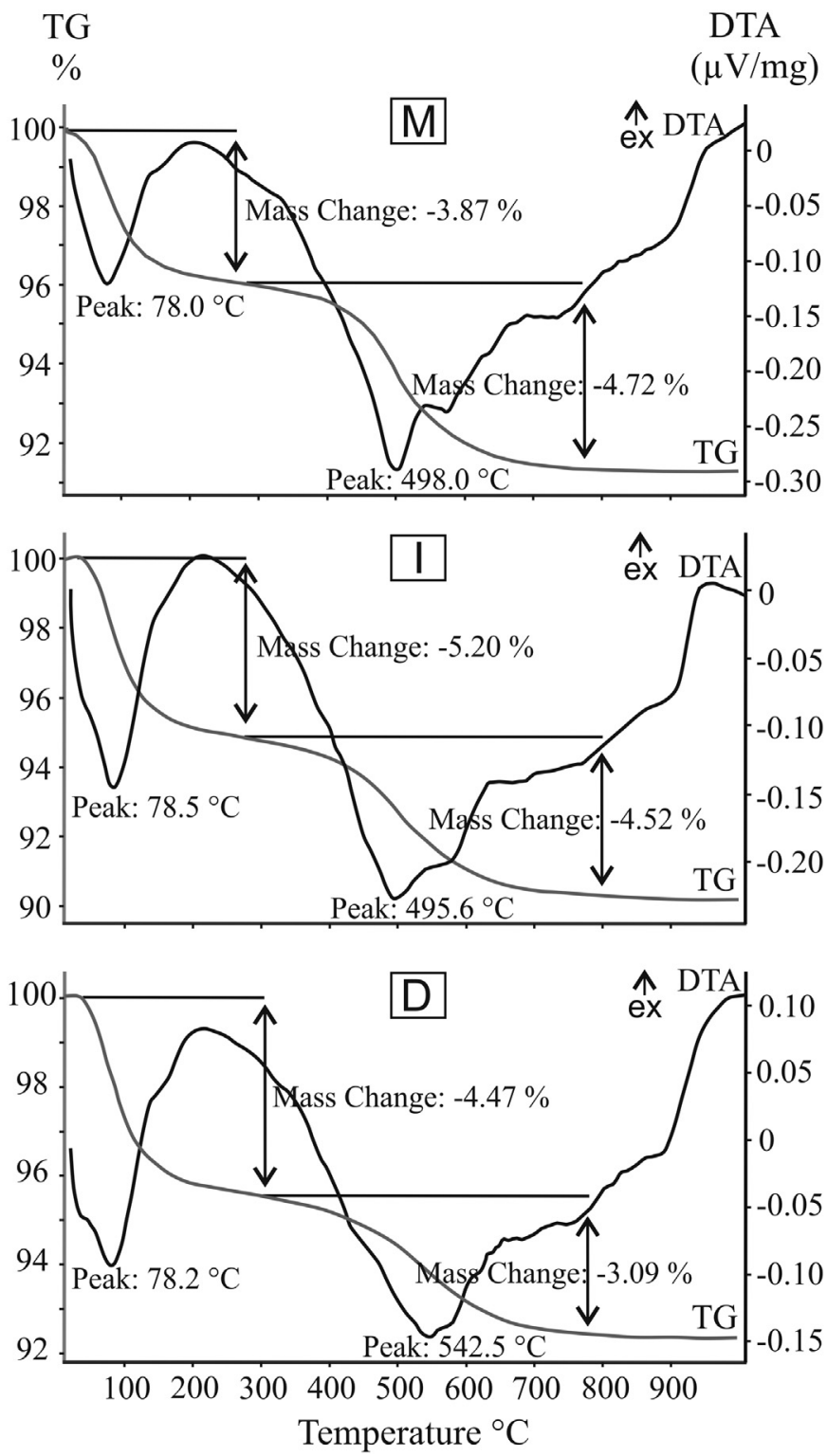

Fig. 7. Thermoanalytical (TG-DTA) curves of samples D, I and M, fractions $<2 \mu \mathrm{m}$.

line with other methods as well as published data (Azzi et al., 2016).

\subsection{X-ray diffraction}

Illite and interstratified illite-smectite are the main clay minerals in the studied samples (Fig. 9; Table 2; Azzi et al., 2016). Smectite is present in all samples. The lowest smectite content has been found in the sample I. The highest amount of kaolinite and interstratified kaolinite-smectite has been found in the sample M (Fig. 9; Table 2; Azzi et al., 2016).

Fig. 9 shows the XRD patterns for samples D, I and M after drying by sunlight and force drying at $100{ }^{\circ} \mathrm{C}, 200{ }^{\circ} \mathrm{C}$ and $300{ }^{\circ} \mathrm{C}$. A noticeable decrease on the intensity $\mathrm{d}=15 \AA$ of the expandable clay minerals and gentle broadening of these peaks occurs at $200{ }^{\circ} \mathrm{C}$ and $300{ }^{\circ} \mathrm{C}$. However, no increase has been observed for the $d=9.96 \AA$ peak as result of smectite interlayer breakdown to illite layers. Such behavior is able to describe as partial and heterogeneous smectite interlayer space collapse. The XRD patterns after ethylene glycol solvation show the same behavior for all samples (Fig. 9). It indicates that partial collapse of smectite interlayer space was repaired by ethylene glycol solvation.

\subsection{Thermal analysis}

DTA-TG curves of all clay samples show the maximum loss of adsorbed water occurring at temperatures around $80^{\circ} \mathrm{C}$ (Fig. 7). Sample I showed the highest loss of adsorbed water while sample $\mathrm{M}$ showed the lowest value. Loss in the interlayer water ranges mainly from $100{ }^{\circ} \mathrm{C}$ to $200{ }^{\circ} \mathrm{C}$ and continues to over $300^{\circ} \mathrm{C}$ when dehydroxylation reaction begins. Dehydroxylation reaction has the maximum loss around $500^{\circ} \mathrm{C}$. The large temperature range in the dehydroxylation reactions is related to the presence of more than one clay minerals phase in the samples (Fig. 9, Table 2, Azzi et al., 2016). Based on the thermal analysis results, rehydration tests at temperatures of $100^{\circ} \mathrm{C}, 200^{\circ} \mathrm{C}$ and $300{ }^{\circ} \mathrm{C}$ were performed in order to check if forced dried samples are able to rehydrate.

\subsection{Rehydration test}

The results and behavior of all three studied samples were practically same during the rehydration test. The increasing of drying temperature caused weight differences related to water release. The relative differences between drying forced samples were practically unchanged during rehydration (Fig. 10). Small decrease in weight after drying at $100{ }^{\circ} \mathrm{C}$ is due to samples pre-treatment (drying at $105^{\circ} \mathrm{C}$ for $24 \mathrm{~h}$ ), in order to provide the same starting conditions to all samples. Moisture content was determined after $1 \mathrm{~h}, 14 \mathrm{~h}$ and $24 \mathrm{~h}$ (Fig. 10). Samples D, I and $\mathrm{M}$ dried at $200{ }^{\circ} \mathrm{C}$ and $300^{\circ} \mathrm{C}$ have reached moisture equilibrium after $14 \mathrm{~h}$ with a gain in the moisture content of respectively 2 and $1.5 \mathrm{wt} . \%$, once the same value was observed also after $24 \mathrm{~h}$ (Fig. 10). Although for samples D, I and $\mathrm{M}$ dried at $100{ }^{\circ} \mathrm{C}$, the equilibrium were not achieved after $24 \mathrm{~h}$, once the moisture values showed a continuous increase comparing $1 \mathrm{~h}, 14 \mathrm{~h}$ and $24 \mathrm{~h}$. Samples D, I and M dried at $100{ }^{\circ} \mathrm{C}$ and after $24 \mathrm{~h}$ at lab conditions showed a moisture gain of about 3 wt.\% (Fig. 10).

\subsection{Fourier transform infrared spectroscopy}

MIR spectra for sunlight dried and forced dried $\left(100^{\circ} \mathrm{C}, 200^{\circ} \mathrm{C}\right.$ and 

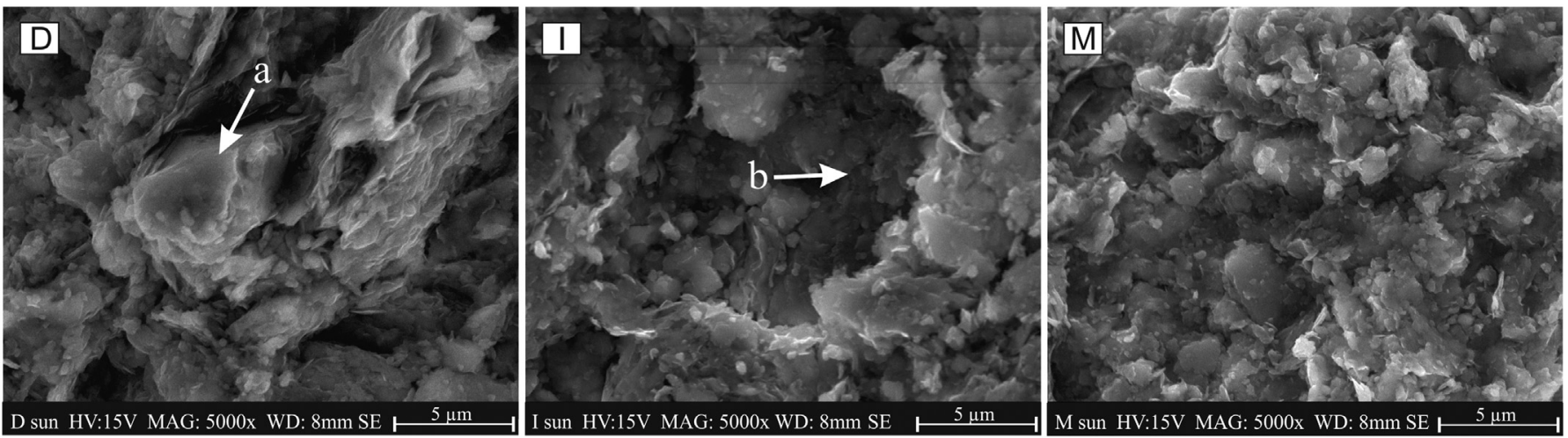

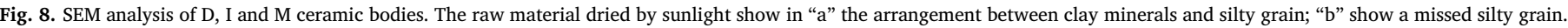

$300^{\circ} \mathrm{C}$ ) samples D, I and $\mathrm{M}$ (fraction $<2 \mu \mathrm{m}$ ) show no changes between the different drying temperatures (Fig. 11). Even for the $\mathrm{OH}$ groups the intensity of absorbed bands has not decreased. It suggests that dehydroxylation reactions have not occurred up to $300{ }^{\circ} \mathrm{C}$ evidencing any structural changes, and also correlating with DTA-TG analysis.

\section{Discussion}

The studied clayey raw materials from CDSG are essentially illitic (Table 2; Dondi et al., 2014; Azzi, 2014; Azzi et al., 2016). The presence of swelling clay minerals, mainly small amount of smectite (Fig. 9, Table 2), however, resulted in negative changes of technological parameters after forced drying at $200{ }^{\circ} \mathrm{C}$ and $300{ }^{\circ} \mathrm{C}$ (Figs. 2-6, 10). One of the most common features of smectite is the ability to expand and collapse at the interlayer space. Removal of smectite interlayer water molecules can occur from a decrease in relative humidity and an increase in temperature (e.g. Derkowski et al., 2012). Thermal analysis (Fig. 7) and drying experiments (Figs. 4, 5, 10) have shown that samples forced dried at $100{ }^{\circ} \mathrm{C}$ have lost mainly adsorbed water. These results are in accordance with thermal analysis showing at $100{ }^{\circ} \mathrm{C}$ the loss in the adsorbed water and at $200{ }^{\circ} \mathrm{C}$ and $300^{\circ} \mathrm{C}$ the dehydration in which expandable clay minerals loses the interlayer water (e.g. Środoń and McCarty, 2008; Salles et al., 2010; Kuligiewicz and Derkowski, 2017). Samples forced dried at $100{ }^{\circ} \mathrm{C}$ remain with significant amount of interlayer water, keeping the interlayer spacing and rehydrated even after $24 \mathrm{~h}$ of drying (Fig. 10). It demonstrated that only slight changes have occurred during the technological tests comparing with samples that were dried by sunlight (Figs. 2-5).

The rehydration test demonstrated that higher forced drying temperatures $\left(200^{\circ} \mathrm{C}\right.$ and $\left.300^{\circ} \mathrm{C}\right)$ caused noticeable damages on the moisture absorption capacity (Fig. 10). This phenomenon was observed for all studied samples regardless of small differences in mineral composition (Fig. 9, Table 2, Azzi et al., 2016). Besides temperature, the factors responsible for the partial and heterogeneous smectite interlayer space collapse of samples forced dried at 200 and $300^{\circ} \mathrm{C}$ (Fig. 9), could be higher layer charge, heterogeneity of interlayer cations and distribution of layer charge. In clay rocks from the Corumbataí (Fm) the smectite is mainly product of illite weathering (Zanardo, 2003; Azzi et al., 2016). The assumption that smectite from the studied samples has at least slightly higher layer charge that low layer charge smectites is in an agreement with observation of Šucha et al. (1993) who found that smectites of non-volcanic origin (weathered illites) have higher layer charge than smectites of volcanic origin. The elevated temperatures $\left(200-300^{\circ} \mathrm{C}\right)$, along with other factors, may account for formation of a mixture of mono- (11.8-12.9 $\AA$ ) and bi-hydrated state (14.5-15.8 $\AA$ ). Decrease in intensity of 001 smectite peak and slight shift to $14.4 \AA$ with relatively significant maximum was determine at the most compact sample D dried at $300{ }^{\circ} \mathrm{C}$ (Fig. 9). It showed still a dominant presence of bi-hydrated state (Ferrage, 2016). Significant broadening of 001 peak of air dried samples was distinguished at more weathered and less compact samples (I and $\mathrm{M}$ ) that were forced dried at 200 and $300^{\circ} \mathrm{C}$. Broad shoulder from 13.58 to $15.2 \AA$ (I) and from 13 to $15.2 \AA$ (M) was observed after forced drying at $300^{\circ} \mathrm{C}$ (Fig. 9). Such broadening can be explained by random and partly segregated layer sequences mainly of bi- and mono-hydrated states (Ferrage, 2016). EG saturation of studied samples eliminated the differences observed in airdried XRD patterns after different forced drying temperatures (Fig. 9). The EG fully reopened smectitic interlayer space with two-layer structure (17 $\AA$ ) however the water (air-dried XRD patterns) did not do that for samples forced dried at 200 and $300{ }^{\circ} \mathrm{C}$. It has been reported that EG is able to intercalate also anhydrous smectite (Svensson and Hansen, 2010; Szczerba et al., 2014).

The presence of swelling clays in the rock increase the moisture content due to swelling and provide greater plasticity to the ceramic tiles, especially during shaping and drying (Singer and Singer, 1963; Reeves et al., 2006; Ouahabi et al., 2014). However, when the studied clays were exposed to those forced drying $\left(100,200\right.$ and $\left.300{ }^{\circ} \mathrm{C}\right)$ the swelling ability was inhibited causing silty/sandy-like behavior (i.e. lower plasticity (Fig. 4) and cohesion between grains (Fig. 5)) of originally swelling clay materials. Plasticity and consistency analyses for samples forced dried at 200 and $300{ }^{\circ} \mathrm{C}$ indicated high permeability and low cohesion.

According to Dondi et al. (2014), increase of the non-plastic (coarse) fraction lowers plasticity of samples which was confirmed in our tests by difficulties during pressing of the materials forced dried at 200 and $300^{\circ} \mathrm{C}$.

All three studied samples have similar mineral composition (Fig. 9, Table 2, Azzi et al., 2016). However, slight differences in some of their properties were observed likely due to slight variation in mineralogy. Sample M has the lowest linear shrinkage from all three studied samples despite the highest amount of phyllosilicates verified by the quantitative XRD analysis (Azzi et al., 2016). The lowest linear shrinkage for sample $M$ can be related to the higher content of non-swelling clay minerals, especially kaolinite (Table 2). On the other hand, the highest linear shrinkage for sample I correspond well with the highest amount of dioctahedral clay minerals (Table 2; Azzi et al., 2016) and the highest mass (water) loss $<200^{\circ} \mathrm{C}$ (Fig. 7). The linear shrinkage values decreased with increasing forced dried temperature. A possible explanation could be related to phyllosilicates dehydration (loss of the interlayer water) during the forced drying and their lower rehydration during the ceramic body preparation when batch achieves $9.5 \mathrm{wt} . \%$ of moisture.

Lower bending strengths of both green and dried tiles measured for sunlight dried sample D corresponds with higher amount of non-clay minerals (i.e. coarser fraction), compared to the samples $\mathrm{M}$ and I (Figs. 2, 3; Galos, 2011; Azzi et al., 2016). Forced dried samples showed a loss of their bending strengths (Table 1). This can be explained by 


\section{Counts}

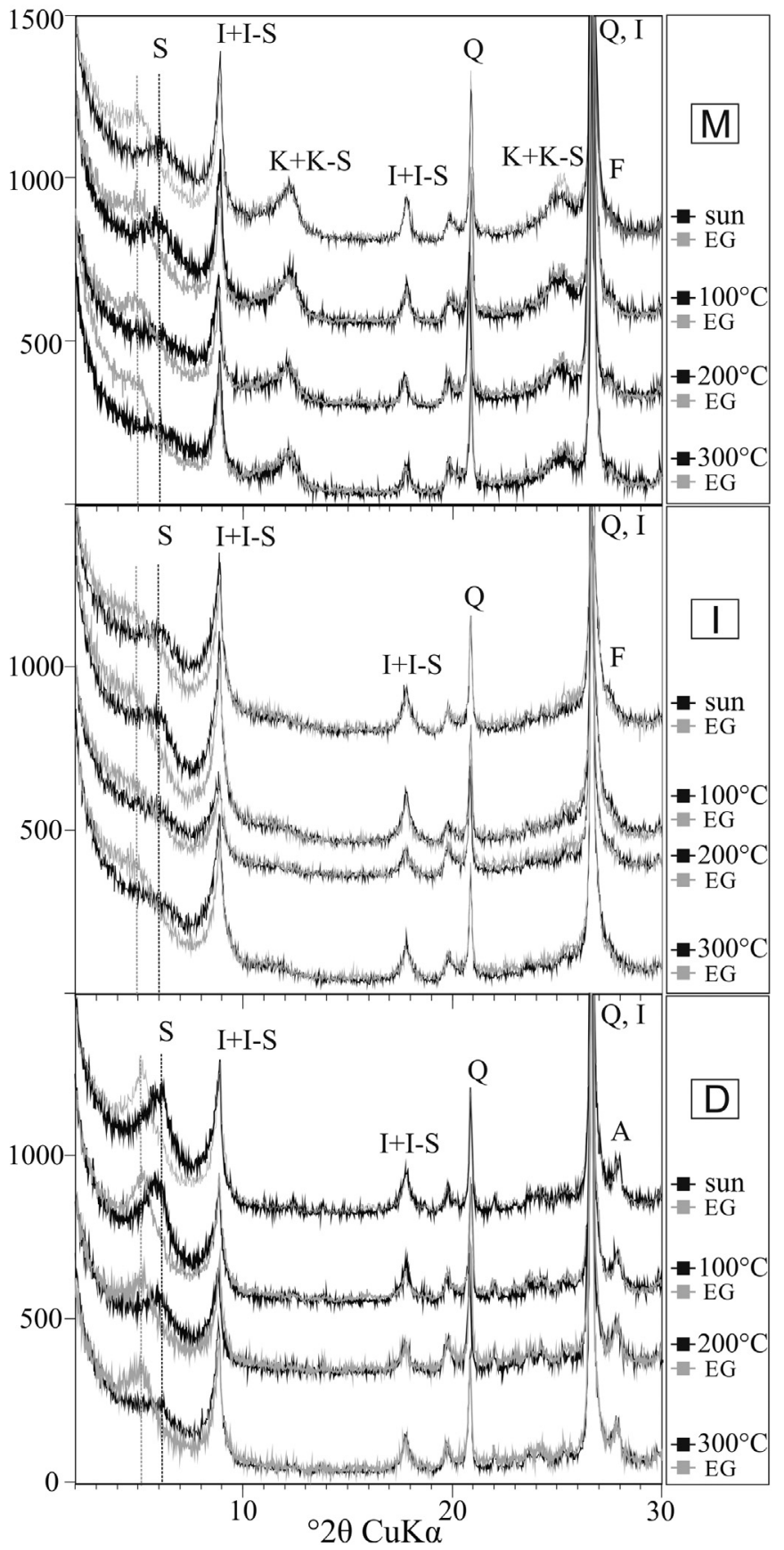

Fig. 9. XRD patterns of oriented specimens from size fractions $<2 \mu \mathrm{m}$, air dried and after ethylene-glycol solvation (EG). Samples D, I and M dried by sunlight (sun), and force dried at $100{ }^{\circ} \mathrm{C}, 200^{\circ} \mathrm{C}$ and $300{ }^{\circ} \mathrm{C}$. S - smectite, I - illite, I-S - interstratified illite-smectite, $\mathrm{K}$ - kaolinite, K-S - interstratified kaolinite-smectite, Q - quartz, F - K-feldspar and A albite.

Table 2

Semiquantitative estimation of clay minerals composition of fraction $<2 \mu \mathrm{m}$ on base XRD patterns (Fig. 11) and detailed clay minerals identification (Azzi et al., 2016). \% S percentage of expandable interlayers in interstratified minerals, $\operatorname{tr}-$ traces, $<1 \%$.

\begin{tabular}{lllll}
\hline & $\begin{array}{l}\text { Illite }+ \text { illite-smectite } \\
(>10 \% \mathrm{~S})\end{array}$ & Smectite & $\begin{array}{l}\text { Kaolinite + kaolinite-smectite } \\
(30 \% \mathrm{~S})\end{array}$ & Chlorite \\
\hline $\mathrm{D}$ & 87 & 13 & & $\mathrm{tr}$ \\
$\mathrm{I}$ & 95 & 5 & $\operatorname{tr}$ & \\
$\mathrm{M}$ & 84 & 6 & 10 & \\
\hline
\end{tabular}

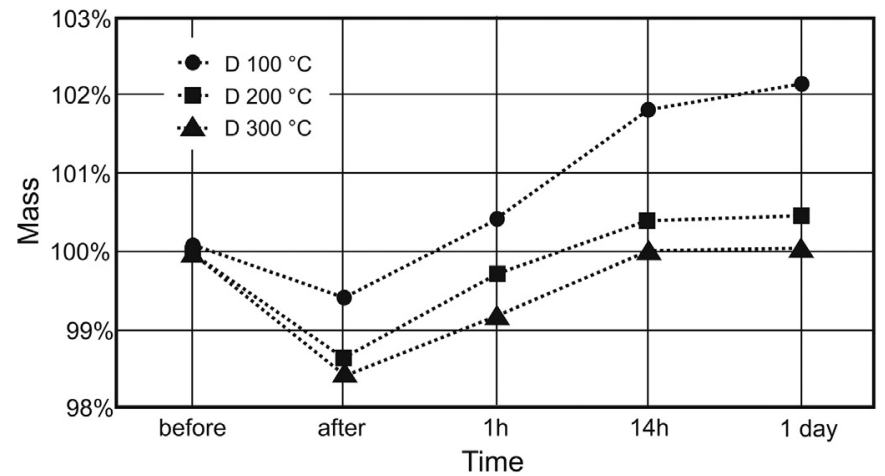

Fig. 10. Rehydration test of sample D after drying forced at $100{ }^{\circ} \mathrm{C}, 200^{\circ} \mathrm{C}$ and $300{ }^{\circ} \mathrm{C}$. Before - pre-treated starting material before the test, After - percentage of weight of pretreated starting material after drying at $100,200,300^{\circ} \mathrm{C}$, respectively. Samples M and I have similar behavior. Dotted line is provided to guide the eye only.
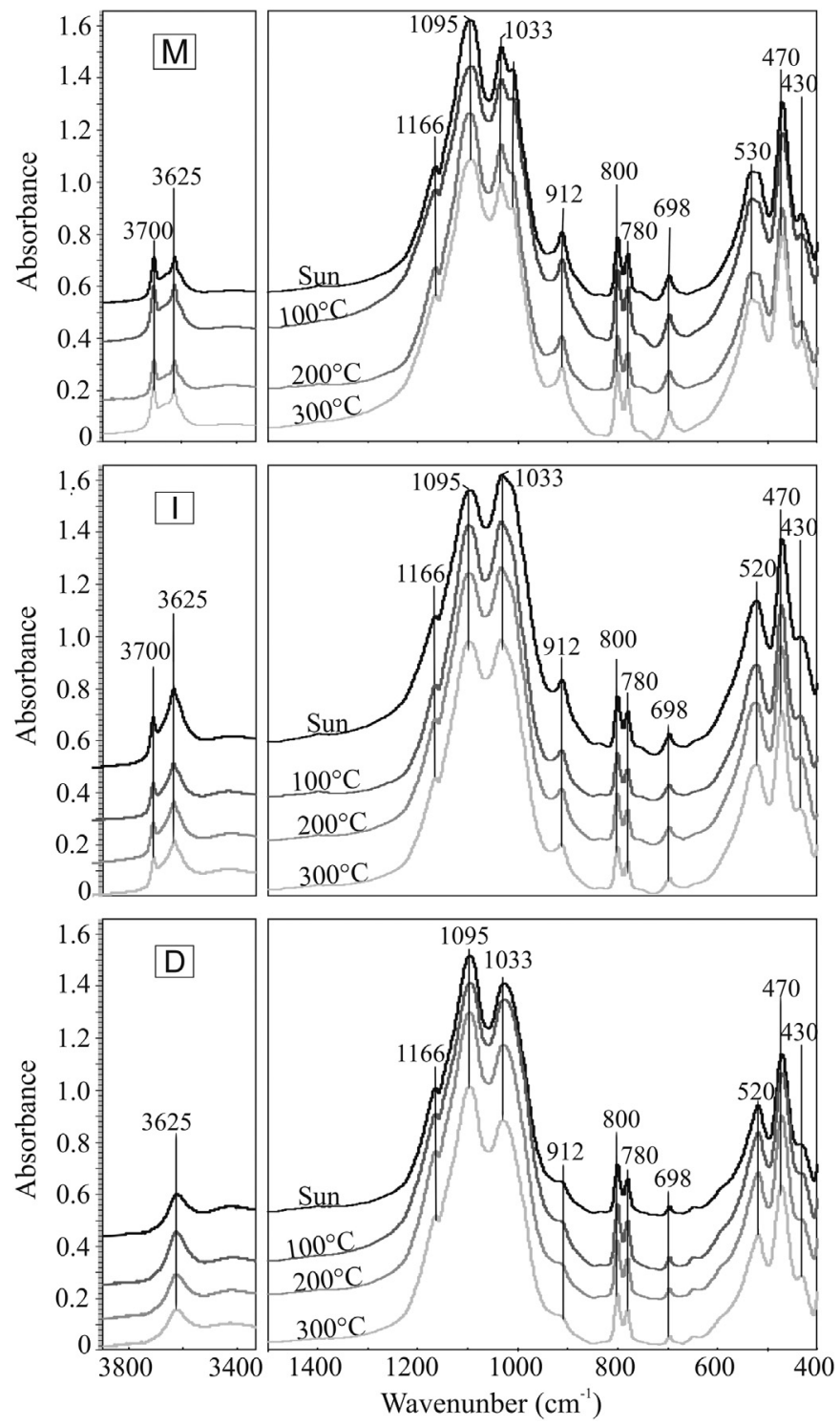

Fig. 11. MIR spectra of samples D, I and $M$ for fractions $<2 \mu \mathrm{m}$ dried by sunlight (sun), and drying forced at $100{ }^{\circ} \mathrm{C}, 200{ }^{\circ} \mathrm{C}$ and $300^{\circ} \mathrm{C}$. 
increase of coarser fraction after drying and grinding (Figs. 2, 3). During the tile pressing, the arrangement of coarser particles can produced more empty spaces that directly affect the bending strengths. The variations in bending strength decrease are attributed the heterogeneity of clay materials in terms of porosity and particle size distribution. In addition sample $\mathrm{M}$ which raw material was dried at $200{ }^{\circ} \mathrm{C}$ and $300{ }^{\circ} \mathrm{C}$ was the only one that had produced tiles with fragile edges and horizontal cracks (Fig. 6). Sousa and Holanda (2005) correlate high pressure in pressing to the susceptibility of samples to produce cracks, fissures and warpage. It was also observed for sample $\mathrm{M}$ drying forced at 200 and $300{ }^{\circ} \mathrm{C}$ (Fig. 6) after using the highest pressure at pressing of tiles. Results of the bending strength test did not point out the fragility of the tiles, for example if the edges of the tiles could withstand the treadmill transportation during the entire tilemaking process.

According to description of advantages and disadvantages of rotary dryers and fluidized-bed dryers (Trojosky, 2009), the rotary dryers seem to be better solutions for clays from CDSG. The advantages of rotary dryers are simple installation and rapid commissioning, operation capacity up to $150 \mathrm{t} / \mathrm{h}$, non-sensitive to size fraction of material and to operating errors, suitability to install in the open and low specific electric power consumption (Trojosky, 2009). The ceramic companies should adjust temperature (the optimum at many industrial minerals is drying air temperature of about $400^{\circ} \mathrm{C}$; Trojosky, 2009), time of drying, amount and size of the clayey rock fragments. The most important is keep in mind the effects demonstrated here and its consequences if the raw material with smectite in its composition reach temperatures higher than $100{ }^{\circ} \mathrm{C}$.

\section{Conclusions}

The results show significant influence of drying temperature on properties of ceramic clays from the Ceramic District of Santa Gertrudes. The dehydration of smectite and the increase of the coarser fraction were main changes after forced drying that affected also the other technological properties. The present study also suggests a way for ceramic companies how they could proceed with the drying of the ceramic clays from the CDSG:

- The major clay mineral of studied clayey rocks from Corumbataí (Fm) is illite. Small admixture of smectite, however, increase the plasticity of raw materials. The sensitivity of smectite to forced drying might reduce the quality of ceramic materials at the same. Samples that were forced dried at $200^{\circ} \mathrm{C}$ and $300{ }^{\circ} \mathrm{C}$ have their rehydration compromised suggesting that swelling clay minerals have lost their interlayer molecular water, collapsed and were not able to fully rehydrate.

- After grinding, samples that were forced dried at $200{ }^{\circ} \mathrm{C}$ and $300{ }^{\circ} \mathrm{C}$ showed a noticeable increase in coarse size fraction $(>100 \mu \mathrm{m})$. The changes in the size distribution of the raw material after drying and grinding along with smectite dehydration affected significantly consistence, plasticity and partly degraded dried tiles.

- According to mineralogical and technological characterization, the presence of swelling clay minerals helps the batch to generate tiles with good plasticity. To keep the same properties of the batch that have been dried by sunlight is necessary to adjust application of commercial dryers. Based on the results obtain in the present study, it is recommended to keep the temperature on the surface of clayey raw materials not much higher than $100^{\circ} \mathrm{C}$. The more precise value (between 100 and $200^{\circ} \mathrm{C}$ ) should be investigated.

- Understandings of the raw materials process allow using it with different purposes. For example, raw materials with higher plasticity could be forced dried to reach temperatures between $200{ }^{\circ} \mathrm{C}$ and $300{ }^{\circ} \mathrm{C}$ to decrease plasticity. These changes could be advantageous to the ceramic industries. Higher amount of very weathered clay beds that have been avoid by now because of their higher plasticity could be forced dried and used to compose the batch mixture with proper plasticity, decreasing the mine waste.

\section{Acknowledgements}

The authors acknowledge the PDSE-CAPES scholarship (grant number 2999/13-7); Slovak Research and Development Agency (grant APVV-15-0292) for support, Slovakia Academy of Sciences, Comenius University of Bratislava, SENAI - Rio Claro and UNESP - Rio Claro for the use of laboratories for sample analyses; and are grateful to Rogers Rocha for his help with sample preparation.

\section{References}

ABNT, 1997. Placas cerâmicas para revestimentos: especificação e métodos de ensaios: 13818. Rio de Janeiro. 78 pp.

ACIMAC/MECS, 2015. World Production and Consumption for Ceramic Tiles, $3^{\text {rd }}$ Edition. www.acima.it.

Adamcová, R., Frankovská, J., Durmeková, T., 2009. Engineering geological clay research for a radioactive waste repository in Slovakia. ActaGeologicaSlovaca 1 (2), 71-82.

Anfacer, 2016. 2016: Brazilian Association of Manufacturers of Ceramic Tiles, Sanitary Ware and Related Products, São Paulo. http://www.anfacer.org.br.

Azzi, A.A., 2014. A influência da temperatura na secagem forçada da matéria-prima cerâmica da Formação Corumbataí na região do Polo de Santa Gertrudes (SP). Ph.D. Thesis. Universidade Estadual Paulista, Rio Claro, Brazil.

Azzi, A.A., Curtolo, M.Z., Zanardo, A., 2015. Sensibilidade à secagem da matéria-prima cerâmica da Formação Corumbataí na região do Polo Cerâmico de Santa Gertrudes, SP. Cerâmica 61, 236-243.

Azzi, A.A., Osacký, M., Uhlík, P., Čaplovičová, M., Zanardo, A., Madejová, J., 2016. Characterization of clays from the Corumbataí formation used as raw material for ceramic industry in the Santa Gertrudes district, São Paulo, Brazil. Appl. Clay Sci. (132-133), 232-242.

Cabral Junior, M., de Carvalho Gamba, Carlos Tadeu, Tanno, L.C., dos Santos Almeida, Amilton, da Cruz, Tomas Teodoro, 2013. Potencial das reservas de argila para o suprimento do polo cerâmico de Santa Gertrudes - SP: Onde o Recurso Mineral faz a Diferença. Ceram. Ind. 18 (2), 10-16.

Campos, L.F.A., de Macedo, R.S., Kiyohara, P.K., Ferreira, H.C., 1999. Características de plasticidade de argilas para uso em cerâmica vermelha ou estrutural. Cerâmica 45, 140-145. http://dx.doi.org https://doi.org/10.1590/S0366-69131999000500006.

Celik, K., 2010. Technological characterization and industrial application of two Turkish clays for the ceramic industry. Appl. Clay Sci. 50 (2), 245-254.

Christaras, B., 1991. A comparison of the Casagrande and fall cone penetrometer methods for liquid limit determination in marls from Crete. Greece. Eng. Geol. 31, 131-142. http://dx.doi.org/10.1016/0013-7952(91)90002-3.

Christofoletti, S.R., Moreno, M.M.T., 2011. Sustentabilidade da mineração no pólo cerâmico de Santa Gertrudes, São Paulo - Brasil. Ceram. Ind. 16 (3), 35-42.

Corma, P., 2008. Innovations and innovative processes in the Castellón ceramic district. Qualicer 59-78. http://www.qualicer.org/recopilatorio/ponencias/pdfs/0813051e. pdf (P.BA).

Derkowski, A., Drits, V.A., McCarty, D.K., 2012. Rehydration of dehydrated dehydroxylated smectite in a low water vapor environment. Am. Mineral. 97, 110-127.

Dondi, M., 1999. Clay materials for ceramic tiles from the Sassuolo District (Northern Apennines, Italy). Geology, composition and technological properties. Appl. Clay Sci. 15 (3-4), 337-366.

Dondi, M., Raimondo, M., Zanelli, C., 2014. Clays and bodies for ceramic tiles: reappraisal and technological classification. Appl. Clay Sci. 96, 91-109. http://dx.doi.org/10. 1016/j.clay.2014.01.013.

Ferrage, E., 2016. Investigation of the interlayer organization of water and ions in smectite from the combined use of diffraction experiments and molecular simulations. A review of methodology, applications, and perspectives. Clay Clay Miner. 64 (3), 348-373.

Ferrari, S., Gualtieri, A.F., 2006. The use of illitic clays in the production of stoneware tile ceramics. Appl. Clay Sci. 32 (1-2), 73-81.

Galos, K., 2011. Composition and ceramic properties of ball clays for porcelain stoneware tiles manufacture in Poland. Appl. Clay Sci. 51 (1-2), 74-85.

Gliozzo, E., Iacoviello, F., Foresi, L.M., 2014. Geosources for ceramic production: the clays from the Neogene-Quaternary Albegna Basin (southern Tuscany). Appl. Clay Sci. 91-92, 105-116.

Henry, E.D., 1952. Clay technology in ceramics. Clay Clay Miner. 1 (1), 257-266.

Holtz, R.D., Kovacs, W.D., 1981. An Introduction to Geotechnical Engineering. PrenticeHall, Inc., New Jersey.

Kuligiewicz, A., Derkowski, A., 2017. Tightly bound water in smectites. Am. Mineral. 102, 1073-1090.

Lahcen, D., Hicham, E.E., Latifa, S., Abderrahmane, A., Jamal, B., Mohamed, W., Meriam, E., Nathalie, F., 2014. Characteristics and ceramic properties of clayey materials from Amezmiz region (Western High Atlas, Morocco). Appl. Clay Sci. 102, 139-147.

Medhioub, M., Hajjaji, W., Hachani, M., Lopez-Galindo, A., Rocha, F., Labrincha, J.A., Jamoussi, F., 2012. Ceramic tiles based on central Tunisian clays (SidiKhalif formation). Clay Miner. 47 (2), 166-175.

Moore, D.M., Reynolds Jr., R.C., 1997. X-Ray Diffraction and the Identification and Analysis of Clay Minerals, 2nd ed. Oxford Univ. Press, Oxford.

Moreno, M.M.T., Zanardo, A., Rocha, R.R., Roveri, C.D., 2012. Matéria-prima da formação Corumbataí na região do pólo cerâmico de Santa Gertrudes, SP, com 
características naturais para fabricação de argila expandida. Cerâmica 58, 342-348. Moreno, M.M.T., da Rocha, R.R., Godoy, L.H., 2014. Major elements geochemistry of sedimentary rocks from Corumbataí formation, Santa Gertrudes Ceramic Pole, São Paulo, Brazil. Geomaterials 4, 11-17.

Moreno, M.M.T., Roveri, C.D., Godoy, L.H., Zanardo, A., 2016. Caracterização de argilas e composição de massas cerâmicas preparadas com base na análise de curvas de consistência de misturas argila-água. Cerâmica 62, 21-31. http://dx.doi.org https:// doi.org/10.1590/0366-69132016623611954.

Motta, J.F.M., Christofoletti, S.R., Garcez, L.L., Florêncio, R.V.D.S., Boschi, A.O., Moreno, M.M., Cuchierato, G., Zanardo, A., 2004. Características do Pólo de Revestimentos Cerâmicos de Santa Gertrudes - SP, com ênfase na produção de argilas. Ceram. Ind. 9 (1), 1-6.

Nassetti, G., 1989. Technological and productive innovations in the ceramic industry with particular reference to ceramic floor and wall tiles. Mater. Sci. Eng. A109, 417-425.

Njoya, D., Hajjaji, M., Njopwouo, D., 2012. Effects of some processing factors on technical properties of a clay-based ceramic material. Appl. Clay Sci. 65-66, 106-113.

Oikonomopoulos, I.K., Perraki, M., Tougiannidis, N., Perraki, T., Kasper, H.U., Gurk, M., 2015. Clays from Neogene Achlada lignite deposits in Florina basin (Western Macedonia, N. Greece): a prospective resource for the ceramics industry. Appl. Clay Sci. 103, 1-9.

Oliveira, M., Zanardo, A., de Carvalho, S.G., da Rocha, R.R., 2016. Características mineralógicas e granulométricas das fontes de poeiras no Polo Cerâmico de Santa Gertrudes - SP. Cerâmica 62, 198-205.

Ouahabi, M., Daoudi, L., Fagel, N., 2014. Mineralogical and geotechnical characterization of clays from northern Morocco for their potential use in the ceramic industry. Clay Miner. 49 (1), 35-51. http://dx.doi.org/10.1180/claymin.2014.049.1.04.

Reeves, G., Sims, I., Cripss, J.C., 2006. Clay Materials Used in Construction. Special Publication, London, Geological Society (525 pp.).

Rocha, R.R., Zanardo, A., Moreno, M.M.T., 2008. Estudo do comportamento reológico de barbotinas preparadas com argilas da Formação Corumbataí utilizadas no pólo cerâmico de Santa Gertrudes (SP). Cerâmica 54, 332-337.

Ryley, M.D., Sherwood, P.T., 1970. An investigation of a cone-penetrometer method for the determination of the liquid limit. Géotechnique 20, 203-208. http://dx.doi.org/ 10.1680 /geot.1970.20.2.203.

Salles, F., Bildstein, O., Douillard, J.M., Jullien, M., Raynal, J., Van Damme, H., 2010. On the cation dependence of interlamellar and interparticular water and swelling in smectite clays. Langmuir 26 (7), 5028-5037.

Singer, F., Singer, S.S., 1963. Industrial Ceramics. Springer-Science Business Media, B.V. (1455 pp.).

Sousa, S.J.G., Holanda, J.N.F., 2005. Development of red wall tiles by the dry process using Brazilian raw materials. Ceram. Int. 31, 215-222.

Środoń, J., McCarty, D.K., 2008. Surface area and layer charge of smectite from CEC and EGME/ $\mathrm{H}_{2} \mathrm{O}$-retention measurements. Clay Clay Miner. 56 (2), 155-174.

Šucha, V., Kraus, I., Gerthofferová, H., Peteš, J., Sereková, M., 1993. Smectite to illite conversion in bentonites and shales of the east Slovak Basin. Clay Miner. 28, 243-253.

Svensson, P.D., Hansen, S., 2010. Intercalation of smectite with liquid ethylene glycol resolved in time and space by synchrotron X-ray diffraction. Appl. Clay Sci. 48, $358-367$.

Szczerba, M., Klapyta, Z., Kalinichev, A., 2014. Ethylene glycol intercalation in smectites. Molecular dynamics simulation studies. Appl. Clay Sci. 91, 87-97.

Trojosky, M., 2009. Selection criteria for the use of dryers in the mineral raw materials, chemical and recycling industries. Cement Int. 3, 58-68.

Vieira, C.M.F., Sánchez, R., Monteiro, S.N., 2008. Characteristics of clays and properties of building ceramics in the state of Rio de Janeiro, Brazil. Constr. Build. Mater. 22, 781-787.

Zanardo, A., 2003. Pesquisa geológica e de matérias-primas cerâmicas do centro nordeste do estado de São Paulo e vizinhanças. Universidade Estadual Paulista, Rio Claro, Brazil.

Zanardo, A., Costa, M.N.D.S., Del Roveri, C., Moreno, M.M., Rocha, R.R., Carvalho, S.G., 2011. Hidrotermalismo na Formação Corumbataí, Permiano da Bacia do Paraná, na região de Rio Claro, estado de São Paulo - Brasil. VII Congr. Ibérico Geoquímica, pp. 1-6. 